\title{
BIOLOGY OF HIPPODAMIA VARIEGATA (GOEZE) (COLEOPTERA: COCCINELLIDAE), ON APHIS FABAE SCOPOLI (HEMIPTERA: APHIDIDAE)
}

\author{
Reza Jafari*
}

Faculty of Agriculture, Borojerd Islamic Azad University, Borojerd, Iran

Received: February 12, 2010

Accepted: March 11, 2011

\begin{abstract}
Hippodamia variegata (Goeze) is a among natural enemy of bean aphid so far identified in the world. In this study, the duration of hatching, larval instars and pupal stages of $H$. variegata feeding on black bean aphid, Aphis fabae Scopoli were investigated under laboratory conditions $\left(25 \pm 1^{\circ} \mathrm{C}, 60 \pm 5 \%\right.$ relative humidity and 16:8 (light:darkness) hours photoperiod. The mean pre-oviposition period of $H$. variegata was $6.20 \pm 0.13$ days and the oviposition period was $43 \pm 0.21$ days. The female beetles laid on an average $943.90 \pm 53.53$ eggs and the hatching \% was $82.86 \pm 3.12$. The average incubation period was $3.35 \pm 0.11$ days and the duration of total larval period from egg to adult was $16.5 \pm 0.13$ days. The pre-pupal and pupal periods were $1.40 \pm 0.16$ and $3.10 \pm 0.07$ days, respectively. The mean longevity of the male and the female beetles were $50 \pm 3.2$ and $55.5 \pm 3.37$ days, respectively.
\end{abstract}

Key words: Hippodamia variegata, development, Aphis fabae

\section{INTRODUCTION}

Aphids are a diverse group of plant feeding insects belong to family Aphididae of order Hemiptera, predominantly found in temperate climate zones such as north America, Europe, Central and Eastern Asia (Nelson and Rosenheim 2006). They cause damage directly by sucking cell sap, secrete honeydew resulting in development of sooty mould on leaves and shoots and directly as vectors of certain plant viruses (Kennedy et al. 1962; Raboudi et al. 2002). Aphis fabae Scopoli, commonly known as black bean aphid, is the most important polyphagous species of pest and attacks the bean plant and over hundred host plants including vegetables, fruits trees and ornamental by the nymphs and the adults of aphid cause damage by sucking the sap from the tender shoots, pods, flowers and reduce the market value (Volkl and Stechmann 1998).

In Iran the bean growers use various insecticides to control black bean aphid. Insecticidal control is not only expensive but also its residues left over the sprayed surface of the crops or in the soil and have become a matter of concern of environmental pollution. The indiscriminate use of pesticides causes phytotoxicity and destruction of beneficial organisms such as predators, parasitoids, microorganisms and pollinators (Luckman and Metcalf 1978). Global warning has cautioned us and the adverse consequences of insecticide use are always alarming and also inducing pest out break because of pest resistance. These entomological backlashes have compelled the scientists to be concerned with entomologically compatible pest management programs (Hodek 1970). Therefore, use of natural enemies in biological control is a good pest management tactic to minimize the population level of invasive pests (Delfoss 2005). Investigation into the potential use of predatory insects or mites to control aphid pests received a greater attention for a reduction of chemical damages to the environment.

The ladybird beetles have been known worldwide as a predator of a number of insects. They are the most commonly known of all beneficial insects (William 2002). The coccinellid beetles are considered to be a great economic importance in agro-ecosystem through their successful employed in the biological control of many injurious insect (Agarwala and Dixon 1992). The degree of their adaptation as well as their efficiency in controlling aphid populations observed varies with the species and the environmental conditions (Dixon 2000). They are of great economic important as predators both in their larval and adult stages on various important crop pests such as aphids, coccids and other soft bodied insects (Hippa et al. 1978; Kring et al. 1985), while the species Hippodamia variegata feed on many insect pests such as aphids, psyllids, white flies, lepidopteron insects and mealy bug (Franzman 2002).

The species of the genus Hippodamia have been identified so far in the word are reported as Aphid predators in all agro-ecosystems. Several of them have been identified as potential biological control agents of bean aphid in agricultural crops (Fan and Zhao 1988 ). The voracious feeding of injurious aphids by Hippodamia spp. keep them as appropriate effective biological control agents (Kontadimas and Stathas 2005). The searching ability of this 
winged predators, enable them for better locating and identifying aphid colonies under outdoor and indoor conditions as compared to other aphids natural enemies. According to Debach and Rosen (1991) a predator is a reliable regulator of its prey at low densities, if he has a great capacity for research, which would enable it to prevent the prey of causing economic damage. A similar concept has also been demonstrated by Pedigo (2004) if a predator is an effective regulator of its prey, it is able to regulate its population at low densities and prevent inflict damage to the host plant. In this context, the voracious aphid predator $H$. variegata (palaearctic species), is reported as one of the most important bio-control agents of black bean aphid in agricultural crops and it is now released in many countries to control Aphis fabae.

The study of the life history and the feeding behavior of $H$. variegata under laboratory conditions may evaluate its predatory impacts on black bean aphid pest for better utilization in integrated aphid control program. The study of the biology of $H$. variegata would help to use this insect for in proper biological control. Lack of research on the biology and its beneficial utilization leads to the present work.

\section{MATERIALS AND METHODS}

Collection and mass culture of $H$. variegata and $A$. fabae

To maintain the culture of black bean aphid, sugar beet (Beta vulgaris) and common bean (Phasaeolus vulgaris) were grown in the micro-plots sized $2 \times 3$ meter, plants were maintained at experimental field of the Department of Culture, Faculty of Agricultural Sciences, Boroujerd Islamic Azad University, Boroujerd, Iran.

A culture of large number of larvae and adult predator of $H$. variegata was established in the laboratory in order to supply necessary insects for the experiment. For this reason, some males and females of the $H$. variegata were collected by sweep net from the unsprayed horticulture field and were confined in cages $\left(7 \times 7 \times 7 \mathrm{~cm}^{3}\right)$. Black bean aphids were also collected daily they free on infested bean leaves, stems, twigs and inflorescences from the same unsprayed field and supplied as food. These beetles were sexed and paired in Plexiglas cage $\left(6 \times 11 \times 23 \mathrm{~cm}^{3}\right)$. The bottom of the cages was covered with blotting paper.

\section{Study of biology}

During intensive observation the leaves containing $H$. variegata eggs were collected immediately after egg laying and transferred in the Petri dishes (12 cm diameter). Egg laid by each female during 24 hours were counted and kept in separate Petri dish to determine the total number of eggs laid per female and also hatching period as well as hatching percentage of eggs were recorded. After hatching of eggs, the larvae were then transferred individually in Petri dishes (15 cm diameter) and reared on black bean aphids. Fresh bean shoots infested with aphids were placed in each Petri to provide food for the larvae every morning. The larvae were observed daily at $12 \mathrm{hrs}$ interval until pupation. Side by side, the exuvae found in each of vials was removed when the larva entered into the next in- star. Total number of aphid consumed by each larva, dead and unconsumed aphids were counted daily and were replaced by fresh aphids. They multiply parthenogenetically and their density increased rapidly on the growing points of plants. The larvae and pupae of $H$. variegata were collected from naturally infested field crops and kept in incubator for adult emergence. The condition maintained in incubator was $25 \pm 1^{\circ} \mathrm{C}$ temperature coupled with, $60 \pm 5 \%$ relative humidity and the photoperiod 16:8 (L : D). Freshly emerged adult beetles were reared on black bean aphid in pairs in Plexiglas $\left(6 \times 11 \times 23 \mathrm{~cm}^{3}\right)$. A blotting paper was spread over its inner surface for egg laying. Fecundity, longevity and sex ratio were recorded. The emerged adults were sexed and confined in pairs in the Petri dishes and fed on black bean aphids. Sufficient food (A. fabae of various stages) was supplied regularly. Egg masses were collected and reared as above and continued for several times for obtaining large number of larvae and adult predators. Regular observations were made on the leaves of aphid-infested. Ten replications were used in this case.

\section{Statistical analysis}

The Data were analyzed by Analysis of variance (ANOVA) and the mean values were separated by Duncan multiple range test (DMRT). All analysis were performed using SAS, version 7.

\section{RESULTS AND DISCUSSION}

\section{Development}

The developmental stages of $H$. variegata observed as egg, four larval instars, pupa and adult. Egg is elongate, oval and generally pale yellow color. Gradual color changes occur from yellow to orange during the incubation period. Eggs were laid either singly or in the form of patches (17-25 eggs/site). Larva is blackish in color with many long branched hairs and black patches on upper surface of the body. The larval period during I and II instars were more active with a preference to prey eggs. The same phenomenon for III and IV instars utilizing more nymphal and adult prey stages was recorded. As the larva matures, it becomes Yellowish, with black spots on the dorsal surface. All prey stages were attacked by the four larval stages as well as the adult predator. This kind of prey feeding was also reported by some researchers (Elhagh and Zaiton 1996; Kontadimas and Stathas 2005). But larval stages of the predator prefer immature stages of prey aphid whereas adult predator was mostly observed feeding either nymph or adult prey aphid. Pupa is the only inactive stage of the coccinellid with flattened blackish color at early pupal stage that turned later into orange reddish before emerging as adult stage. Medium reddish adult predator emerged from pupa and searched different sites of leaf lamina for A. fabae. Kontadimas and Stathas (2005), also reported similar feeding ability by $H$. variegata. The drop excretion on tip of cornicle by bean aphids was reported as a barrier of predation while these phenomena was observed without any negative effect on the rate of prey aphid feeding by $H$. variegata. This was due to the strong mandibles of the predator. 
Table 1. Life cycle of H. variegate reared on A. fabae

\begin{tabular}{|l|c|c|c|}
\hline \multirow{2}{*}{ Different stages } & \multicolumn{3}{|c|}{ Duration of days } \\
\cline { 2 - 4 } & minimum & maximum & mean \pm SE \\
\hline Pre-oviposition period & 6 & 7 & $6.20 \pm 0.13$ \\
\hline Ovioisition period & 37 & 48 & $3.35 \pm 0.11$ \\
\hline Incubation period & 3 & 4 & $3.35 \pm 0.11$ \\
\hline Total larval period & 13 & 18.5 & $16.5 \pm 0.13$ \\
\hline Pre-pupal period & 1 & 2 & $1.40 \pm 0.16$ \\
\hline Pupal period & 3 & 3.5 & $3.10 \pm 0.07$ \\
\hline Total period from egg to adult & 20 & 23.5 & $21.35 \pm 0.39$ \\
\hline Longevity of the beetle & 30 & 70 & $55.50 \pm 3.37$ \\
\hline
\end{tabular}

Table 2. Larval-instar diuration of H. variegata reared on Aphis fabae

\begin{tabular}{|l|c|c|}
\hline \multicolumn{1}{|c|}{ Larval-instar } & Mean & \pm SE \\
\hline First & 3.5 & 0.17 \\
\hline Second & 3.05 & 0.2 \\
\hline Third & 3.3 & 0.11 \\
\hline Fourth & 3.65 & 0.13 \\
\hline
\end{tabular}

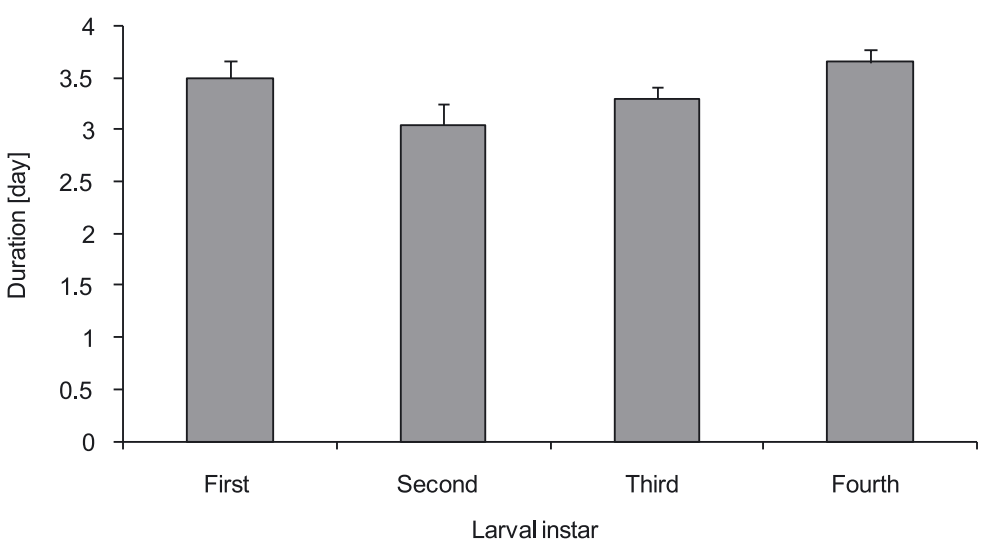

Fig. 1. Duration (mean $\pm \mathrm{SE}$ ) of different larval instars of $H$. variegata reared on A.fabae

\section{Oviposition}

The pre-oviposition period of H. variegata was 6 to 7 days with an average of $6.20 \pm 0.13$ days (Table 1). Lanzoni et al. (2004) observed that the pre-oviposition period was 7 day. Elhagh and Zaiton (1996) studied that the pre-oviposition period was 6 to 7 days, which is similar to the present findings.

The oviposition period in the present study was 37 to 48 days (Table 1), and the mean oviposition period was $43 \pm 0.21$ days. Elhagh and Zaiton (1996) reported that the period of $H$. variegata lasted from 35 to 48 days using $A$. $f a-$ bae as food, which is similar to the present observation.

The incubation period was 3 to 4 days with an average of $3.35 \pm 0.11$ days (Table 1). Elhabi et al. (2000) observed that the incubation period of $H$. variegata was 3 days. However, Lanzoni et al. (2004) and Grigorov (1977) reported that it was 3 and 3 days respectively using bean aphid as host. These results seem to be close with the present observation.

The mean of total larval period (1st instar to 4th instar) was $16.5 \pm 0.13$ days (Table 1$)$. Kontadimas and Stathas (2005) observed that the total period of $H$. variegata was 15 days using Dyaphis crataegi as food, which is low- er than the present finding. Grigorov (1977) observed that the total larval period of $H$. variegata varied from 17 to 19 days on bean aphid. This result was higher than the present study. However, Wang et al. (2004) reported that the quality of food and environmental factors like temperature, humidity also play an important role on different aspects of the biology of coccinellid beetles. So, this variation may be due to the quality of food and environmental factors like temperature and humidity.

The newly hatched larval period was 3 to 4 days and on an average of $3.50 \pm 0.17$ days (Table 2). Lanzoni et al. (2004) reported that this period of $H$. variegata was 2 to 3 days using bean aphid as host. This result supported to the present observation. The result of the duration of the 2 nd instar varied from 2 to 4 days and the mean duration was $3.05 \pm 0.20$ days (Table 2). Lanzoni et al. (2004) founded that the duration of the 2nd instar larvae of $H$. variegata was 2.5 to 4 days on aphid, which is comparatively similar to the results of the present findings. Elhabi et al. (2000) founded that the duration of 2nd instar of $H$. variegata varied from 2.5 to 3.5 days using bean aphid as a host. The result indicated that the duration of the 3 rd instar larvae lasted from 3 to 4 days. The mean 
duration of 3rd instar larvae was 3.30 \pm 0.11 days (Table 2). Kontadimas and Stathas (2005) founded that the duration of 3rd instar larvae of $H$. variegata varied from 2.5 to 4 days on cotton aphid. This result supported to the present observation. Observation made on the larval duration of the 4 th instar larvae on an average $3.65 \pm 0.13$ days with minimum of 3 days and maximum of 4 days (Table 2). Lanzoni et al. (2004) reported that the duration of final instar larvae of $H$. variegata was 3 days. Kontadimas and Stathas (2005) found that the duration of 4 th instar larvae of $H$. variegata varied from 2.8 to 3.6 days on cotton aphid. This duration was within the range of present findings.

The pupal period was 3 to 3.5 days with an average $3.10 \pm 0.07$ days (Table 1). Wang et al. (2004) recorded that the mean pupal duration of $H$. varieagata was $4.15 \pm 11$ days when larvae reared on $D$. noxia. Different finding revealed that the pupal period of coccinellid beetles varied with the differences of food and it was correlated with the temperature (Wang et al. 2004).

The number of eggs laid per female were 587 to 1247 with an average $943.90 \pm 53.53$.

The 60 to $70 \%$ of total fecundity was observed within the first 23 days of ovipositional period. The maximum daily fecundity recorded (103 eggs/day) was found correlated with the peak of predation ability. The mean hatching percentage were $82.86 \pm 3.12$. Lanzoni et al. (2004) reported that the number of eggs deposited per female of H. variegata was $900 \pm 80.23$ and $70 \%$ eggs were hatched. Elhabi et al. (2000) observed that the fecundity of female varied from 800-900 eggs with mean 870.5 and with average $79 \%$ eggs were hatched. These results seem to be close with the present findings.

The longevity of adult beetles was counted from the emergence of the adult to its death. The longevity of the male beetles varied from 30 to 62 days with an average of $50 \pm 3.2$ days. Whereas, the longevity of the female beetles varied from 30 to 70 days with an average of $55.5 \pm 3.37$ days. It showed that the longevity of the male beetle was shorter than the female. But there were no significant differences. Elhagh and Zaiton (1996) reported that the adult of H. variegata lived for 32 to 60 days. This result was near similar to the present study. Elhabi et al. (2000) found that the longevity of male and female were $44 \pm 2$ and $61 \pm 9.89$ days. These results are also close to the present observation.

\section{ACKNOWLEDGEMENTS}

The equipment for this study is supported by Islamic Azad University, Boroujerd Branches of Iran. We gratefully acknowledge the Management of this university for their financial and technical support.

\section{REFERENCES}

Agarwala R.K. Dixon A.F.G. 1992. Labratory study of cannibalism and interspesific predation in ladybirds. Ecol. Entomol. 17 (3): 303-330.

Debach P. Rosen D. 1991. Biological Control by Natural Enemies. McMillan com. New York, London, 567.
Delfoss E.S. 2005. Risk and ethics in biological control. Biol. Control 35 (2): 319-329.

Dixon A.F.G. 2000. Insect Predator-Prey Dynamics Lady Birds Beetles and Biological Control. New York. Cambridge Unipress, $257 \mathrm{pp}$.

Elhag E.T.A., Zaiton A.A. 1996. Biological parameters for four coccinellid species in central Saudi Arabia. Biol. Control 7 (3): 316-319.

Elhabi M., Sekkat A., Eljadd L., Boumezzough A. 2000. Biology of Hippodamia variegate and its suitability under greenhouse conditions. J. Appl. Entomol. 124 (9/10): 365-374.

Fan G.H., Zhao J.F. 1988. Functional response of Adonia variegata to cotton aphids. Nat. Econ. Insect 10 (4): 187-190.

Franzman B.A. 2002. Hippodmia variegata a predacious ladybird new in Australia. Aust. J. Entomol. 41 (4): 375-377.

Grigorov S. 1977. Biological peculiarities of some ladybird beetle attacking aphids. Oecologia 87 (4): 401-408.

Hippa H., Kepeken S.D., Laine T. 1978. On the feeding biology of Coccinella hieroglyphica L. (Coleoptera, Coccinellidae). Kevo-subaretitic Ras. Station 14 (2): 18-20.

Hodek I. 1970. Coccinellids and the modern pest management. Bioscience 20: 543-552.

Kennedy J.S., Day M.F., Eastop V.F. 1962. A Conspectus of Aphids as Vectors of Plant Viruses. Commonwealth Inst. Ent., London, 114 pp.

Kontodimas D.C., Stathas G.J. 2005. Phenology fecundity and life table parameters of the predator Hippodamia variegata reared on Dyaphis crataegi. Biocontrol 50 (2): 223-233.

Kring T.J., Gilstrap F.E., Michels G.I. 1985. Role of indigenous coccinellid in regulating green bugs on Texas grain sorghum. J. Econ. Entomol. 78 (1): 269-273.

Lanzoni A., Accinelli G., Bazzocchi G., Burgio G. 2004. Biological traits and life table of the exotic Harmonia axyxidis compared with Hippodamia variegata and Adalia bipunctata. J. Appl. Entomol. 128 (4): 298-306.

Luckman W.H., Metcalf R.L. 1978. The pest management concept. p. 3-35. In: "Introduction to Insect Pest Management". Willey, New York, 257 pp.

Nelson E.H., Rosenheim J.A. 2006. Encounters between aphids and their predators: The relative frequencies of disturbance and consumption. Entomol. Exp. Appl. 118 (1): 211-219.

Pedigo L.P. 2004. Entomology and Pest Management. PrenticeHall of India Pvt. Ltd. New Delhi, 210 pp.

Raboudi F., Benmoussa A., Makni H., Marrakchi M. 2002. Serological detection of plant viruses in their aphid vectors and host plants in Tunisia Bull. OEPP/EPPO Bull. 32 (4): 495-498.

Volkl W., Stechmann D.H. 1998. Parasitism of the black bean aphid (Aphis fabae) by Lysiphlebus fabarum (Hymenoptera, Aphidiidae): the influence of host plant and habitat. J. Appl. Entomol. 122: 201-206.

Wang J., Liyon C., Yang D. 2004. A study on the hunger tolerance of Hippodamia variegata in north Xingjean. J. China Cott. 31 (5): 12-14.

William F.L. 2002. Lady Beetles. Ohio State University Extension Fact Sheet, Horticulture and Crop Science. Division of Wildlife, 2021 Coffey Rd. Columbus, Ohio, 857 pp. 


\section{POLISH SUMMARY}

\section{BIOLOGIA HIPPODAMIA VARIEGATA GOEZE}

(COLEOPTERA: COCCINELLIDAE), NA APHIS FABAE SCOPOLI (HEMIPTERA: APHIDIDAE)

Hippodamia variegata Goeze jest wrogiem naturalnym mszycy fasoli określonym w skali światowej. W pracy, w warunkach laboratoryjnych $\left(25 \pm 1^{\circ} \mathrm{C}, 60-65 \%\right.$ wilgotności względnej i fotoperiodzie 168 godzin - światłości, ciemności), badano czas trwania wylęgu, stadia larwalne i stadia poczwarki H. variegata. Średni okres czasu przed złożeniem jaj $H$. variegata wynosił $6,20 \pm 0,13 \mathrm{dni}$, a okres

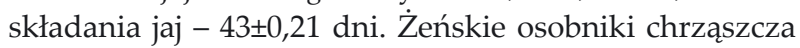
składały średnio $943,90 \pm 53,53$ jaj, a procent wylęgu wynosił $82,86 \pm 3,12$. Średni czas okresu inkubacji wynosił $3,35 \pm 0,11 \mathrm{dni}$, a czas trwania całkowitego okresu larwalnego od jaja do dorosłości - 16,5 \pm 13 dni. Okresy poprzedzające stadium przedpoczwarki i poczwarki wynosiły, odpowiednio $1,40 \pm 0,16$ i 3,10 $\pm 0,07$ dni. Średni czas życia dla chrząszczy męskich i żeńskich wynosił, odpowiednio $50 \pm 3,2$ i 55,5 $\pm 3,37$ dni. 